短報

\title{
山形県日向 I 洞窟出土の弥生時代女性頭蓋について
}

\author{
加藤 稔 $^{1)}$ - 石田 肇 $^{2)}$ \\ 1）山形大学人文学部 \\ 2) 札幌医科大学解剖学第 2 講座
}

要約 山形県日向 I 洞窟から弥生時代に属する女性人骨が発掘された。脳頭蓋が残存 するのみであったが，サイズが大きく長頭型を特徴とする成人女性人骨と推定された。 脳頭蓋の計測値を基にした距離計算では日向の頭蓋骨は縄文よりも, 土井ヶ浜や現代 日本人のそれに近いが，矢状頭頂後頭示数の值のように縄文的な特徴も認められた。

キーワード 頭蓋骨 弥生時代 東北地方 女性

\section{はじめに}

西日本, とくに九州山口地方では, 弥生時代の 人骨が数多く発掘されており，それを基にした 日本人の起源論争あ盛んである（金関他，1960； 内藤, 1971; HANIHARA，1985)。しかし, 東日 本においては, 発見された弥生時代人骨は少な く数えるほどしかない（SUZUKI，1969；小泉・ 今村, 1983)。百々（1983）の報告した塩釜市浦 戸寒風沢島鹿の浜出土の人骨が形態的に弥生時 代から古墳時代に属するのではないかと推定さ れているが, 東北地方の遺跡から出土した弥生 時代人骨としてはここに報告する日向 I 洞窟の 資料が初めてであろう。

\section{遺跡・資料・方法}

日向洞窟遺跡は, 山形県東置賜郡高畠町大字 竹森字姥ヶ作山にある。奥羽山脈の西側, 米沢 盆地の東北部である。「大哀地」低湿地帯に細 長く張り出した海抜 $240 \mathrm{~m}$ 前後の長峰山丘陵の 東麓にある第 I, II 洞窟, 第 III, IV 岩陰と, その
前面の開地遺跡からなる。

人骨が出土したのは, 1955年調査の第 I 洞窟 の上層である。第 I 洞窟は, 入口をほぼ南に向 ける。入口幅 $5 \mathrm{~m}$, 高さ $3.5 \mathrm{~m}$, 奥行は $14 \mathrm{~m}$ あ る。成人女性骨と幼児 2 体の頭蓋骨が発掘され た。伴出遺物は, 弥生時代 II 期の日向式土器で ある。宮城の䲐沼留期に並行する。

この成人人骨についてはすでに一度鈴木尚氏 (当時, 東京大学理学部人類学教室教授) が現 地で観察しており, 成人女性との鑑定を下して いる（柏倉・加藤, 1959）。

頭蓋骨はマルチンの方法に従って計測を行なっ た（KNUSSMANN，1988）。日向および比較す る他の集団の計測值と示数を Table 1 に示す。 また, 頭蓋形態小変異については百々の基準 （百々，1972；DoDO，1974）に従い, その有無 を判定した（Table 2)。

\section{頭蓋の形質（Fig. 1)}

幼児の資料は断片的であるので, ここでは成 人の人骨についてのみ報告をする。蝶後頭軟骨 
Table 1. Comparisons of cranial measurements and indices (Female)

\begin{tabular}{|c|c|c|c|c|c|}
\hline & Hinata & Tsukumo ${ }^{1)}$ & Doigahama ${ }^{2)}$ & Modern ${ }^{3)}$ & S.D. ${ }^{3)}$ \\
\hline 1. Maximum cranial length & 189 & 175.7 & 176.0 & 174.14 & 5.67 \\
\hline 5. Nasion-basion length & 101 & 96.3 & 97.3 & 95.81 & 4.07 \\
\hline 8. Maximum cranial breadth & 141 & 141.9 & 138.1 & 135.95 & 5.03 \\
\hline $8: 1$ & 74.6 & 80.8 & 78.5 & 78.4 & 3.08 \\
\hline 9. Minimum frontal breadth & 100 & 93.8 & 93.0 & 91.18 & 4.06 \\
\hline $9: 8$ & 70.9 & 66.2 & 67.3 & 66.95 & 3.06 \\
\hline 10. Maximum frontal breadth & 121 & 116.9 & 115.1 & 111.91 & 4.99 \\
\hline $9: 10$ & 82.6 & 80.9 & 80.8 & 81.50 & 3.15 \\
\hline 17. Basi-bregmatic height & 138 & 126.1 & 128.1 & 131.05 & 3.98 \\
\hline $17: 1$ & 73.0 & 71.5 & 76.2 & 75.35 & 2.62 \\
\hline $17: 8$ & 97.9 & 89.3 & 92.8 & 96.95 & 4.02 \\
\hline 23. Horizontal circumference & 532 & 506.0 & 506.0 & 498.32 & 15.74 \\
\hline 24. Transverse arc & 324 & 298.4 & 305.1 & 307.5 & 10.18 \\
\hline 25. Median sagittal arc & 388 & 358.7 & 361.2 & 360.36 & 14.09 \\
\hline 26. Frontal arc & 128 & 119.5 & 122.9 & 121.91 & 6.67 \\
\hline $26: 25$ & 33.0 & 33.4 & 34.0 & 34.07 & 1.73 \\
\hline 27. Parietal arc & 139 & 124.1 & 124.1 & 121.77 & 8.01 \\
\hline $27: 25$ & 35.8 & 34.5 & 34.4 & 33.83 & 1.89 \\
\hline $27: 26$ & 108.6 & 103.3 & 101.0 & 100.13 & 7.02 \\
\hline 28. Occipital arc & 121 & 116.7 & 114.2 & 116.41 & 7.54 \\
\hline $28: 25$ & 31.2 & 31.9 & 31.6 & 32.31 & 1.83 \\
\hline $28: 26$ & 94.5 & 96.0 & 92.9 & 95.50 & 6.61 \\
\hline $28: 27$ & 87.1 & 89.3 & 92.0 & 95.81 & 10.90 \\
\hline
\end{tabular}

1) KIYONO and MIYAMOTO (1926); 2) KANASEKI et al. (1960); 3) means and standard deviations by MITSUHASHI (1958)

Table 2. Cranial nonmetric traits

\begin{tabular}{|c|c|c|}
\hline Traits & right & left \\
\hline Metopism & - & \\
\hline Supraorbital nerve groove & - & - \\
\hline Supraorbital foramen & + & - \\
\hline Ossicle at the lambda & - & \\
\hline Interparietals & - & \\
\hline Biasterionic suture & - & - \\
\hline Occipito-mastoid wormians & + & - \\
\hline Parietal notch bone & - & - \\
\hline Condylar canal & + & - \\
\hline Hypoglossal canal bridging & - & - \\
\hline Foramen of HUSCHKE & - & - \\
\hline Foramen ovale incomplete & - & - \\
\hline Foramen of VESALIUS & + & - \\
\hline Aural exostosis & - & - \\
\hline
\end{tabular}

$+:$ present, - : absent
結合および主縫合にはいまだ骨癒合がみられな いことから判断して, この個体の年齢は, 20 歳 台, それる前半であろうと考えられる。性別は, 頭蓋骨が全体的に大きいものの，形態から考え て，女性と推定される。

眉間は突出せず，眉弓も弱い。前頭骨の鼻部， つまり鼻骨および上顎骨と縫合を形成する部分 は陥凹せず, 平坦で幅広い。上下の側頭線, 乳 突上稜は発達しない。外後頭隆起は発達しない が, 最上項線が認められる。下顎窩の前方の関 節面には関節症性の変化が見られた。

頭蓋骨最大長は $189 \mathrm{~mm}$ で女性としてはきわめ て大きい。長幅示数は74.9と長頭型に分類され る。最小前頭幅も $100 \mathrm{~mm}$ で大きい。バジオンブ レグマ高は $138 \mathrm{~mm}$ と頭高も高い。頭蓋形態小変 異では, 眼窩上孔が右側に認められる。舌下神 経管は両側とも欠損する。 

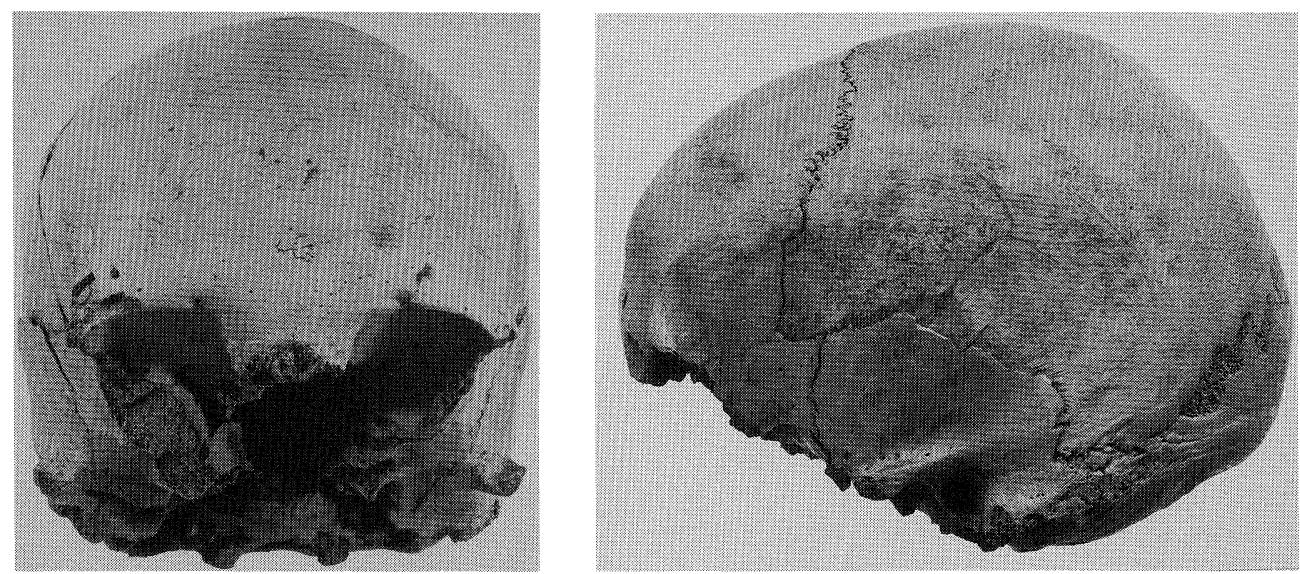

Fig. 1. A female cranium from the Hinata-I cave site, Yamagata Prefecture.

\section{比較}

日向頭蓋骨の計測值と示数を項目のそろう 3 つの女性集団, 津雲縄文時代人（清野・宮本, 1926), 土井ヶ浜弥生時代人（金関他, 1960）お よび関東現代日本人（三橋, 1958）のそれと比 較した (Table 1 )。頭蓋骨長幅示数では, 津雲 縄文時代人は短頭型，他の 2 集団む短頭に近い 中頭型であり，日向とは異なる。バジオンブレ グマ高が日向で高くここれは現代人的である。 正中矢状弧長を除く頭蓋骨計測值11項目を基に ペンローズの形態距離を計算した（PENROSE, 1954)。日向に近いのは関東の現代日本人 (0.39), 渡来系と考えられている土井ヶ浜弥生時代人 (0.41) で、津雲縄文時代人は 0.84 とかなり離 れている。ただ, 公表されている項目数が少な いため，距離計算を行なわなかったが，在来系 と考えられている西北九州の弥生時代人の頭蓋 骨長幅示数は78.2で土井ヶ浜の弥生時代人およ び現代日本人と差がない。このことと顔面頭蓋 がないことを考えあわせると，この日向の人骨 が, 渡来系の弥生時代人の影響を受けていると は即断し難い。

Table 3 には日向および先の 3 集団に北海道 アイヌ（KOGANEI，1893）を加えた 5 集団の
Table 3. Sagittal parieto-occipital index (Female)

\begin{tabular}{lll}
\hline \multicolumn{1}{c}{ Populations } & Index & \multicolumn{1}{c}{ Source } \\
\hline Modern Japanese & 95.8 & MITSUHASHI, 1958 \\
Hokkaido Ainu & 94.2 & KOGANEI, 1893 \\
Doigahama Yayoi & 92.0 & KANASEKI et al., 1960 \\
Tsukumo Jomon & 89.3 & KIYONO \& MIYAMOTO, \\
& & $\begin{array}{l}\text { 1926 } \\
\text { Hinata }\end{array}$ \\
\hline
\end{tabular}

矢状頭頂後頭示数を表している。

Benevolenskaya（1980）は北のモンゴロ イドはこの示数が高く, 東南アジアやヨーロッ パの集団の示数は低いことを見い出した。今回 の比較では, 日向の示数は縄文時代人のそれょ り屯低く, それに対して, 関東の現代日本人は 高い值を示している。北海道アイヌの示数が縄 文時代人ょりも高く, 北方のアジア集団と同程 度の值をむっているが，アイヌの起源を考える 上で, 興味深いことである。

\section{結 論}

日向の頭蓋骨は形態距離の結果では, 縄文よ りあ, 渡来系と考えられている土井ヶ浜や現代 日本人のそれに近いが, 矢状頭頂後頭示数の值 のように縄文的な特徴む見られた。 


\section{文献}

BENEVOLENSKAYA, Y.D., 1980: The world distribution of the occipito-parietal index. In: Recent Problems and New Methods in Anthropology, Nauka, Leningrad, pp. 70-90. (In Russian)

百々幸雄, 1972 : 北海道の古人骨にみられる外耳道 骨腫. 人類学雑誌, $80: 11-22$.

DoDO, Y., 1974: Non-metrical cranial traits in the Hokkaido Ainu and the northern Japanese of recent times. J. Anthrop. Soc. Nippon, 82: 31-51.

百々幸雄, 1983 : 塩釜市浦戸寒風沢島鹿の浜出土の 一人骨. 人類学雑誌, $91: 481-487$.

HANIHARA, K., 1985: Origins and affinities of Japanese as viewed from cranial measurements. In: KIRK, R. and E. SZATHMARY (ed.) Out of Asia: Peopling the Americas and the Pacific. The Journal of Pacific History, Canberra. pp.105-112.

金関丈夫・永井昌文・佐野一, 1960 : 山口県豊浦郡豊 北町土井ヶ浜遺跡出土弥生時代人頭骨について. 人類学研究, 7 (付録) : 1-36.

柏倉亮吉 - 加藤稔, 1959 : 山形県東置賜郡日向洞窟
群. 日本考古学年報, $8: 52-54$.

清野謙次・宮本博人, 1926 : 津雲貝塚人人骨の人類学 的研究. 第 2 部. 頭蓋骨の研究. 人類学雑誌, 41 : 95$140,151-208$.

KNUSSMANN, R., 1988: MARTIN/KNUSSMANN Anthropologie: Handbuch der vergleichenden Biologie des Menschen, Bd. I, Gustav Fischer Verlag, Stuttgart.

KOGANEI, Y., 1893: Beiträge zur physischen Anthropologie der Aino. I. Untersuchungen am Skelet. Mittheil. med. Fak. Univ. Tokyo, 2: 1-249.

小泉清隆・今村啓爾, 1983 : 群馬県岩津保洞窟遺跡 出土の弥生時代人骨について. 人類学雑誌, $91: 238$. 三橋公平, 1958 : 関東日本人頭蓋骨の人類学的研究. 千葉医学雑誌, $34: 248-283$.

内藤芳篤, 1971 : 西北九州出土の弥生時代人骨. 人類 学雑誌, $79: 236-248$.

PENROSE, L.S., 1954: Distance, size and shape. Ann. Eugen., 18: 337-343.

SUZUKI, H., 1969: Microevolutional changes in the Japanese population from the prehistoric age to the present-day. J. Fac. Sci. Univ. Tokyo, Sec. V, 3: 279-308, pls. I-VII. 


\title{
Summary
}

\section{A Human Cranium of the Yayoi Period from the Hinata-I Cave Site, Yamagata Prefecture}

\author{
Minoru KATO $^{1)}$ and Hajime ISHIDA $^{2)}$ \\ 1) Faculty of Literature and Social Sciences, Yamagata University \\ 2) Department of Anatomy, Sapporo Medical College
}

A human cranium was excavated at the Hinata-I cave site, Takenomori, Takahata-cho, Yamagata Prefecture in 1955 (Fig. 1). It was dated at about 2,000 B.P., which corresponds to phase II of the Yayoi period. Dr. Hisashi SUZUKI, professor emeritus of the University of Tokyo, determined that this cranium was that of an adult female (KASHIWAGURA and KATO, 1959).

The Hinata cranium was confirmed, based on macroscopic examination, to be a young female adult in her early twenties because there was no bony fusion of the spheno-occipital synchondrosis or main cranial sutures. The cranium was measured following MARTIN's methods (KNUSSMANN, 1988). The measurement data of the Hinata and the three population samples it was compared to are given in Table 1. The presence or absence data of cranial nonmetric traits, using the criteria of DoDO $(1972,1974)$, are listed in Table 2.

The glabella and supraciliary arch do not protrude. The nasal part of the frontal bone is flat and somewhat wide. The temporal lines and supramastoid ridge are not developed. Although external occipital protuberance is not prominent, the highest nuchal lines are perceptible. Bone erosion is seen in the articular tubercle anterior to the mandibular fossa. The cranial lengthbreadth index was classified as dolichocrany and the basi-bregmatic height is high $(139 \mathrm{~mm})$. The supraorbital foramen is present only on the right side, and the bridging of the hypoglossal canal did not exist on either side.

The measurements and indices of the Hinata cranium were compared with those of three female cranial series, the Tsukumo Jomon (KIYONO and MIYAMOTO, 1926), the Doigahama Yayoi, who are considered to be the immigrant Yayoi people (KANASEKI et al., 1960), and the Kanto Modern Japanese (MITSUHASHI, 1958), as listed in Table 1. PENROSE's shape distances were calculated based on 11 cranial measurements excluding the median sagittal arc. The Hinata is closer to the Doigahama Yayoi $(0.41)$ and the Modern Japanese (0.39) than to the Tsukumo Jomon (0.84).

Table 3 shows the sagittal parieto-occipital index (28:27) in the Hinata, the 3 females series, and a female Ainu series. BENEVOLENSKAYA (1980) pointed out that the northern Mongoloids have high values of this index whereas the indices of the southeast Asian and European are low. Both the Hinata and Tsukumo Jomon have low values of the index, whereas the Modern Japanese have a high value. The index of the Ainu, being higher than that of the Jomon, is as high as those of the northern Asian, which lends more interest to the origin of the Ainu.

The Hinata cranium is closer to the Modern 
Japanese and Doigahama Yayoi than to the Tsukumo Jomon, based on distance analysis, but also has Jomon characteristics such as the sagittal parieto-occipital index.
加藤 稔

Minoru KATO
山形大学人文学部

勇990 山形市小白河町 1 丁目 4-12

Faculty of Literature and Social Sciences, Yamagata University

1-4-12, Kojirakawa-machi, Yamagata 990, Japan 